\title{
Neural simulation-based analysis of the well wall stability while productive seam penetrating
}

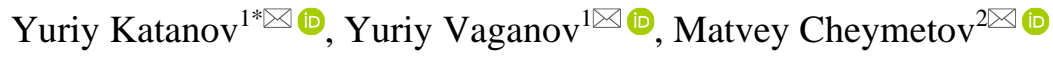 \\ ${ }^{1}$ Industrial University of Tyumen, Tyumen, 625000, Russian Federation \\ ${ }^{2}$ Saint Petersburg State University of Economics, Saint Petersburg, 191023, Russian Federation \\ *Corresponding author: e-mail katanov-juri@ rambler.ru
}

\begin{abstract}
Purpose is the development of mathematical models to evaluate deformation of parameters of the rock mass-well geological and engineering system within the anisotropic media.

Methods. Both mathematical and neural modeling of a stress state of the rock mass-well system under conditions of geological uncertainty has been applied for the studies. From the viewpoint of mathematical modeling, analysis of probability of factors, complicating drilling, should involve a number of assumptions for strength and deformation characteristics of rock mass layers corresponding to particular hole-making conditions.

Findings. A mathematical model of horizontal wellbore and geological layers, occurring along the structure under the conditions of permanent comprehensive stresses, has been developed. An analytical and graphical form has been applied to implement one of the basic aspects of aggregation principles of strength changes in each particular lithological layer for identification of an ideal value of horizontal/inclined wellbore length relative to the rock mass depths scheduled by mining. Regularities of changes in deformation and spatial well stability within the complex reservoirs depending upon various process duties have been determined. A neural simulation-based model has been proposed to analyze deformation of rock mass layers having different strength characteristics.
\end{abstract}

Originality. Interaction between geomechanical characteristics of rock mass as well as deformation and spatial stability of well design has been evaluated both qualitatively and quantitatively.

Practical implications. An opportunity has been presented to forecast deformation of well walls taking into consideration different strength as well as structural and geological rock mass characteristics on the basis of neural simulation. The represented approach has been included on the register of the best scientific-based practices according to "Methods to recover low-pressure gas of Cenomanian producing complex" Project.

Keywords: stress, neural network, deformation, rock pressure, transversely isotropic medium, forecasting, borehole, well

\section{Introduction}

Taking into consideration the effect of local concentrated stress varieties, the basic set of rock mass breaking techniques is based upon the mechanical decomposition of certain solid mass amount into small-size physical components able to higher than internal resistance within the rock structure.

Stresses, favouring following disintegration of rock structure, may happen in following basic cases:

- if action of external forces, arising when specific tools, which hardness is higher than that of the rocks themselves, are used for the rock mass;

- if fluid stream moves under head and at a high rate;

- if water hammer and air blast act;
- if internal forces, formed with the help of highfrequency electromagnetic field and more intensive value of electric field, act (electric breakdown).

Finally, rock mass disintegration processes will be represented by its mechanical disturbance (in varying amounts) when rock compositions and characteristics are preserved. The abovementioned helps qualify them as physical phenomena.

On the other hand, rock mass disintegration may be followed by changes in its composition through different physicochemical processes (i.e. burning, melting, and dissolving). Resulting from such transformations, certain rock mass share will pass into gaseous or vaporous state with other properties which is typical for a physicochemical method of rock mass disintegration [1]. 
Rock mass disintegration with the help of downhole tools (i.e. bore bits, screw-shaped augers, spoon bits etc.) involves such techniques, in terms of which disintegration process of rock structure are exclusively connected with the manifestations of their mechanical properties (i.e. brittleness, strength, fatigue etc.). The stresses, acting in rocks, and exceeding their strength, are formed by means of such mechanical means as impacts, pressure, and vibration. As a result, only rock disintegration processes (i.e. crushing, shearing, breaking-down etc.) will prevail after the effect of such mechanical rock factors [2]-[5].

If rock mass is broken-down without any downhole tools (bitless techniques) then processes of rock structure disintegration will depend upon constant or impulse loads being of explosive nature. Such processes arise in terms of movements of high-pressure liquids; electric charges within the liquids or rocks; and in terms of effects by waves of extension (compression) taking into consideration the rock heating (however, the temperature should not exceed melting processes).

Under the conditions, stresses, exceeding values of connection forces between the composing rock particles or their areas, will form within the rock mass resulting in various disturbances of their continuity.

Productive rock formation $\mathrm{UV}_{1}{ }^{1}$ of Las-Egan oil field, located at the territory of Nizhnevartovsk District (KhantyMansiysk Autonomous National Area Tyumen Region), has been selected as the research object. Las-Egan oil field belongs to Nizhnevartovsk petroliferous region (PFR) of Sredneobsk oil and gas region, which commercial oil and gas content has been identified predominantly within the productive rock masses of Upper Jurassic and Cretaceous deposits. The deposits are in the seams of AB, Ach (Achimov rock unit), and UV groups.

Seams of the represented groups contain base oil reserves of the deposit. Occurrences of the seams are characterized by a complex structure being nonuniform distribution of effective thicknesses, plunging contacts, and numerous replacement zones complicated both lateral and vertical connectivity between reservoirs. On their type, the deposits belong to tabular-arc and bottom water-drive reservoirs with local change in lithology shaping lithologically their areal irregularity as well as complex connectivity.

\section{Materials and methods}

The research involved studies of features and structures of sedimentary rocks; deformational and spatial differences of lithological types; mechanisms to develop neural network models; and their application methods represented in papers by Yu.E. Katanov [6], [7], A.K. Yagafarov [8], [9], I.P. Popov [10], [11], I.I. Nesterov [12], [13], and others.

Studies of the actual values of rock pressure has resulted in the development of a relevant mathematical model based upon the hypothesis of M.M. Protodyakonov concerning both inclined and horizontal mine workings copying geometrically the well trajectories with proper incidence angles [14].

As for the wells, a primary period of rock pressure manifestation relative to the horizontal mine working support (consideration of vertical well share prior to its penetration in a formation) is characterized by changes in the initial stress state of geological mass adjoining the mine working; static period of rock pressure manifestation takes place when the pressure arch is being shaped (supporting is on the formation along the mine working sides). If the wall rock strength is less than the acting stresses then displacement of geological layers, placing lateral pressure on the support, will happen. Against the process, mining of clay argillite and clay will result in their extruding into a mine working in the presence of liquid (rock heaving during its swelling). Secondary (steady) period of rock pressure manifestation starts from the moment of pressure arch formation and changes in critical stresses only within its boundaries.

The period takes into consideration the dynamic rock pressure manifestations in the form of shakes, rock outbursts, and rock bumps corresponding to mechanical stresses within the geological formations neighboring the mine workings [15], [16]. The dynamic manifestations of rock pressure become more intensive in depth involving natural angle of slope of the sliding layers (geological and mathematical analogy of the well trajectory taking into consideration the angle of deviation from the datum axis) [17]-[19].

Implementation of rock mass penetration techniques should provide well-kill safety and exclude mud absorption; processes of destruction of well walls and their narrowing; chemogenic rock flow; and caving processes. Techniques of well drilling using the developed pressure drawdown have become the most popular procedure since it helps minimize mudding of the downhole rock mass areas while applying different drilling agents and natural permeability preserving.

As for the design context, maintaining of well bottom pressure as that one being lower than the formation pressure provokes the necessity to analyze secondary objectives connected with the rock deformation processes taking into consideration borehole stability levels.

Penetration procedure needs identification of maximum pressure drawdown value which may help implement optimum drilling process. The abovementioned requires integration of geomechanical as well as strength and deformation characteristics, and parameters of working stresses and anisotropy prevailing in crosswell space and within bottomholes. If anisotropy of strength and deformation characteristics of rock mass is pronounced then its key penetration factor is borehole orientation according to specific anisotropic axed for each lithological layer [20], [21].

There may be the cases when vertical wells are being drilled with no complicate factors within the selected pressure drawdowns for identical types of drilling agents and pressure drawdown values. At the same time, optimum drilling process for the inclined (horizontal) wells is of probabilistic nature; hence, it may be complicated due to their stability loss.

From the viewpoint of mathematical modeling, the probabilities should involve a number of assumptions for the strength and deformation characteristics of geological layers of rock mass corresponding to the specific well drilling conditions [22]:

- in view of filtration rock mass aspects, probabilistic losses of spatial stability of the inclined boreholes should be analyzed depending upon the maximum permissible total stresses to identify a scope of optimum pressure drawdown values;

- it is expedient to study probabilistic strength and deformation regularities of stability losses by well wall-rock mass along a core axis (vertical axis) and in both tangential directions (two axes within a plane of horizontal expansion of the rock mass);

- alternatives of stress, acting on geological layers (i.e. components of vertical well walls or vertical share of the 
inclined well), will result from various pressure drawdowns being formed, by which values the total stresses within the stress concentrator will be reduced (among other things, it concerns radial direction) owing to the effect of shear (tangential) characteristics favoring horizontal rock disintegration;

- the acting total stresses will also be influenced by incremental owing to the redistribution of other stresses tangential (circular) characteristics together with the relatively constant vertical component; the abovementioned will increase the potential of destruction of layers around the well.

For the cases when open holes are studied, analytical probability calculations as for the formation of specific conditions, in terms of which rock mass layers are loaded (concerning different pressure drawdown values), are implemented involving their anisotropy type identification to evaluate dependencies of stresses acting around the inclined well bores as well as relevant geomechanical characteristics being Young's modulus, Poisson's ratio, and Coulomb's modulus.

Formation of adequate mathematical apparatus should first involve study of a conceptual model of rock deformation process within the interwell space. Developing an approach to simulate regularities of changes in actual stresses within the geological layers will be of special importance for the analysis of horizontal well making as well as inclined ones taking place in highly anisotropic formations.

\section{Results and discussion}

Stress tensor development on the basis of well survey (WS) and the elaborated study of longitudinal well behavior relative to $x, y$, and $z$ axes of geological space (in the main, horizontally) will show that their propagation velocity along $z$ axis (vertical direction) is by 1-2 orders less to compare with $x$ and $y$ directions. The fact speaks for the predominance of several anisotropy types within different layers, i.e. orthotropic, transversely isotropic, and fragmentarily isotropic geological environments.

Conceptual model of the deformation process in the neighborhood of horizontal wells will not be identical for the cases when rock influence on vertical wellbores in the context of any alternatives of the anisotropic environments; the abovementioned depends upon the identity of each intersection point within the peripheries of vertical wellbores.

Analytically, in terms of the idealized cases of isotropic geological environment, all values of actual stresses are represented by means of constants towards the well peripheries while in terms of actual anisotropic formations, values of the stresses will vary similarly to composite a function, which arguments are elastic characteristics of corresponding layers.

If one ties the system of physicomechanical differences of rock mass with the changes in attenuation coefficient of wave amplitude then its vertical excess over a value within the horizontal plane speaks for the availability of fracture system with the horizontal directivity. While core extracting relative to a well axis (isotropy axis), it is required to take into consideration permissible 'shearing' angle of the analyzed samples which should vary within the optimum value interval being $0-45^{\circ}$.

Figure 1 demonstrates horizontal borehole projection of an open well, which walls experience both radial ( $M$ point, shearing, $\sigma_{R}$ - the value will be identical to liquid pressure values for corresponding well) and circular ( $N$ point, $\left.\sigma_{\theta}\right)$ stresses [23].

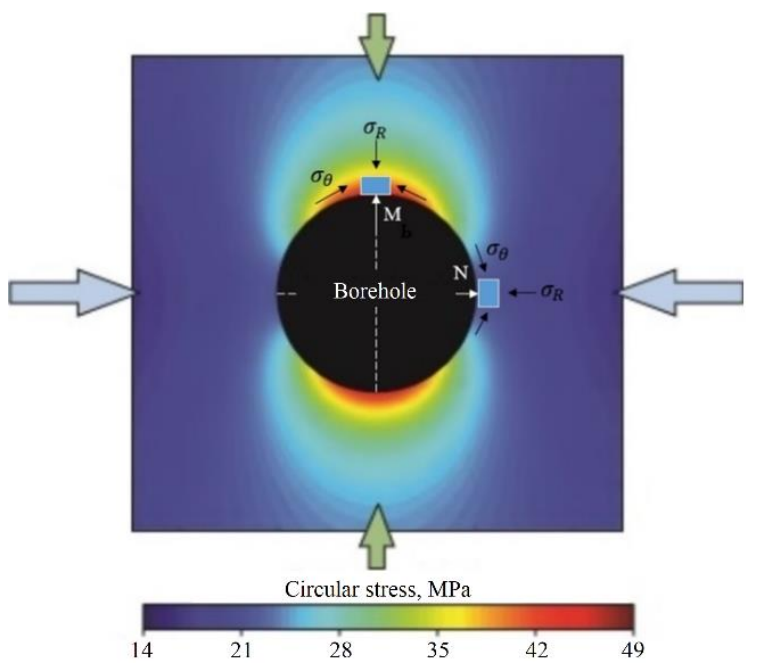

Figure 1. Conditional horizontal projection of circular stress action

Values of circular stresses $\sigma_{\theta}$ will vary regularly while passing from point to point (the represented well periphery involves the assumption that initially the rock mass was of isotropic nature). Maximums of circular stresses as well as tangential ones will be concentrated within $M \wedge N$ points; hence, the values can be represented as their semirange ratio $\left(\frac{\sigma_{\theta}-\sigma_{R}}{2}\right)$.

It should be mentioned that within $M \wedge N$ points, loads of actual stresses $\left(\sigma_{\theta}\right)$ are directed correspondingly perpendicularly and parallely to planes of the rock mass stratification. Thus, liquid pressure drop within the wells will result in the decreased values of radial stresses $\left(\sigma_{R}\right)$ in terms of respective reverse increase of circular stresses $\left(\sigma_{\theta}\right)$ [22].

In the context of any type of geological environment anisotropy, formation of conceptual foundations to study potential distributions of circular stresses $\left(\sigma_{\theta}\right)$ in the neighborhood of horizontal wells should take into consideration their axes in parallel with isotropic planes (i.e. continuum). Mine pressure differentials of the studied depths in terms of liquid pressure values corresponding to them in each well may be assumed as a unit of stress distribution within the rock mass.

A borehole may also be damaged resulting from the integrated effect of stratigraphic and structural factors; if they prevail, all unstable layers will superpose more competent rock mass intervals in the neighborhood of the geological structure edge. Consequently, relative displacement of the formation will happen as well as cement damage and casing collapse (Fig. 2).

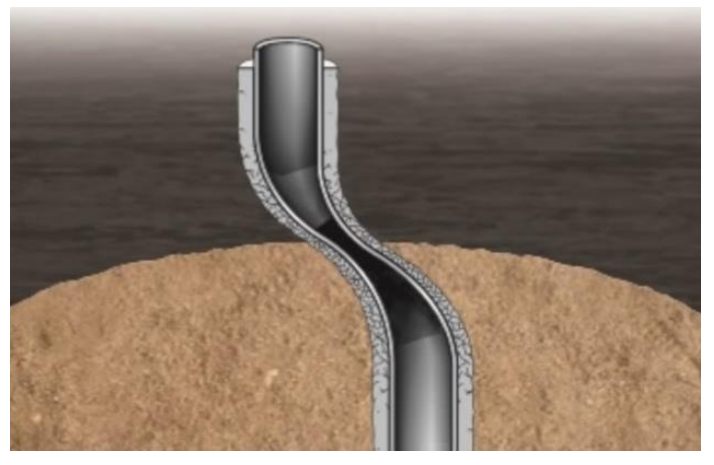

Figure 2. Borehole instability upon the lithological layers 
Figure 3 shows schematically the regularities of changes in actual stresses $\left(\sigma_{1}, \sigma_{2}, \sigma_{3}\right)$ relative to $x, y$, and $z$ core axes of the analyzed well: $\sigma_{1}=\sigma_{R} ; \sigma_{2}=\sigma_{\theta} ; \sigma_{3}=\sigma_{z}$. Since it is expedient to study core samples within the projections of quasi three dimensional models, Figure 3 represents conditional dependences in $Q 3 D$ form with $0_{y}$ axis limitation.

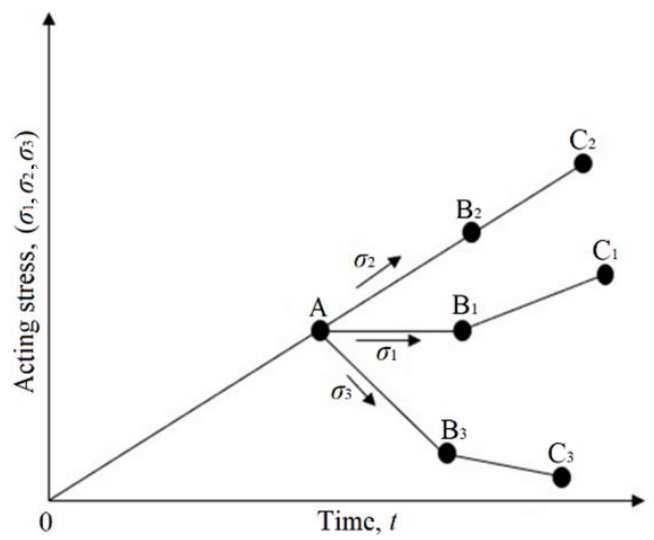

Figure 3. Schematic representation of the compressive strain of rock mass along the walls of horizontal wells

Any geological extent is influenced comprehensively by stresses differentiated as the differences in modulus between the values of initial formation pressure $P_{0 . \text { in }}$ (section $0 A$ ) and rock pressure $P_{r}$. Point $A$ corresponds to the total stress values on the rock matrix before well drilling started.

Following $\sigma_{\theta}$ loading continues its increase ( $A B_{2}$ section) and $\sigma_{1}$ stress (related $A B_{1}$ section) will remain constant in terms of $\sigma_{3}$ decrease (related $A B_{3}$ section) for the rock pressure values at the specific depths. $B_{1}, B_{2}, B_{3}$ points will correspond to the conditions when the studied well will be drilled completely and filled with the required liquid volumes.

Alternatives of changes in pressure drop process within the studied well correspond to $B_{1} C_{1}, B_{2} C_{2}, B_{3} C_{3}$ sections. In terms of the process, $\sigma_{3}$ will approach close to zero and $\sigma_{1}, \sigma_{2}$ (i.e. relevant $B_{1} C_{1}$ and $B_{2} C_{2}$ sections) will start its increase. The process will last until complete core sample disintegration.

Lame's equation system, represented in the linear analytical form, may be used as the initial mathematical basis to calculate $\sigma_{1}, \sigma_{2}$, and $\sigma_{3}$, stresses being identical holistically to pressure drawdowns in a well:

$T^{(i)}=\sigma_{i}+P_{\text {gas }}$,

where:

$T^{(i)}$ - complete stress tensor;

$\sigma_{i}$-values of complete stresses taking into consideration rock pressure effect for the specific depths;

$P_{\text {gas }}-$ is gas pressure value.

In the expanded form, system (1) is represented with the help of following equations:

$$
\left\{\begin{array}{l}
\sigma_{R}(r)=-\left(P_{h o r}+P_{w}\right) \cdot\left(\frac{R_{w}}{r}\right)^{2}+P_{h o r}+P_{\text {mass }}(r) \\
\sigma_{\theta}(r)=\left(P_{h o r}+P_{w}\right) \cdot\left(\frac{R_{w}}{r}\right)^{2}+P_{h o r}+P_{\text {mass }}(r) \\
\sigma_{Z}(r)=P_{\text {hor }}+P_{\text {mass }}(r)
\end{array}\right.
$$

where:

$P_{h o r}-$ is rock pressure value;

$P_{w}$ and $P_{\text {mass }}(r)$ - pressure values within a well, and within the rock mass "point" at $r$ distance from the well axis respectively;

$R_{w}$ - the well radius value.

Tangential stress values may be represented as follows:

$$
\sigma_{\tau}=\frac{1}{2} \cdot\left(\sigma_{R}(r)-\sigma_{\theta}(r)\right)=-\left(P_{h o r}+P_{w}\right) \cdot\left(\frac{P_{w}}{r}\right) .
$$

Taking into consideration $r=R_{w}$ equation on a wall well, it follows from formula 2 that the stress values will be equal to:

$$
\left\{\begin{array}{l}
\sigma_{R}\left(R_{w}\right)=0 \\
\sigma_{\theta}\left(R_{w}\right)=2 \cdot\left(P_{h o r}+P_{w}\right) . \\
\sigma_{Z}(r)=P_{h o r}+P_{w}
\end{array}\right.
$$

Well pressure drawdowns $\Delta P_{w}$ will be connected with $\sigma_{\theta}$ stresses, acting on its wall, as:

$$
\Delta P_{w}=P_{h o r}+P_{g a s}-\frac{\sigma_{\theta}}{2},
$$

where:

$P_{\text {gas }}$ - value of gas formational pressure.

Characteristic points of a loading process, represented conditionally in Figure 3, will correspond to following stress values:

$-\sigma_{1}=\sigma_{2}=\sigma_{3}=P_{\text {hor }}+P_{\text {gas }}$ within $A$ point;

$-\sigma_{1}=P_{\text {hor }}+P_{\text {gas }}$ within $B_{1}$ point;

$-\sigma_{2}=2\left(P_{h o r}+P_{\text {gas }}\right)$ within $B_{2}$ point;

$-\sigma_{3}=0$ within $B_{3}$ point;

- within $A B_{1}, A B_{2}$, and $A B_{3}$ sections, average stress value $\sigma_{m}=\frac{\left(\sigma_{1}+\sigma_{2}+\sigma_{3}\right)}{3}$ will remain constant as it follows from expression system (2);

- within $B_{1} C_{1}, B_{2} C_{2}$, and $B_{3} C_{3}$ sections, engaged in pressure drawdown increase simulation relative to $\sigma_{1}, \sigma_{2}$, and $\sigma_{3}$ stresses, reverse discharge of core samples will take place relative to their initial loading values with the selected additional loading increment. In the process of pressure drawdown simulation in a well, the increment is $25 \mathrm{~atm}$ for rock samples of $\mathrm{PK}_{1}$ object of the Cenomanian system. Orientation is towards the loading units ( $M$ and $N$ points).

Involving the represented mathematical model, neural network modeling has been applied [23], [24] to forecast in core sample the deformation increase in terms of the increased acting stresses (Figs. 4-7) corresponding to the depth of the studied site of $3200 \mathrm{~m}$ well.

The effect on a core sample, directed towards $M$ point, resulted in massive stepped deformation [1]. The initial disintegration of its structure and continuity, starting from such pressure drawdown values as 20-40 atm, has become the consequence in terms of corresponding creep of interwell space rocks with further pressure drawdown increase. The effect on another core sample, directed towards $N$ point, identified regularity of its structure change, corresponding to a model of elastic-plastic deformation according to which disintegration is achieved if pressure drawdowns are more than $150 \mathrm{~atm}$. The creep of the prevailing layers will be almost nonavailable until greater pressure drawdown values are formed. 


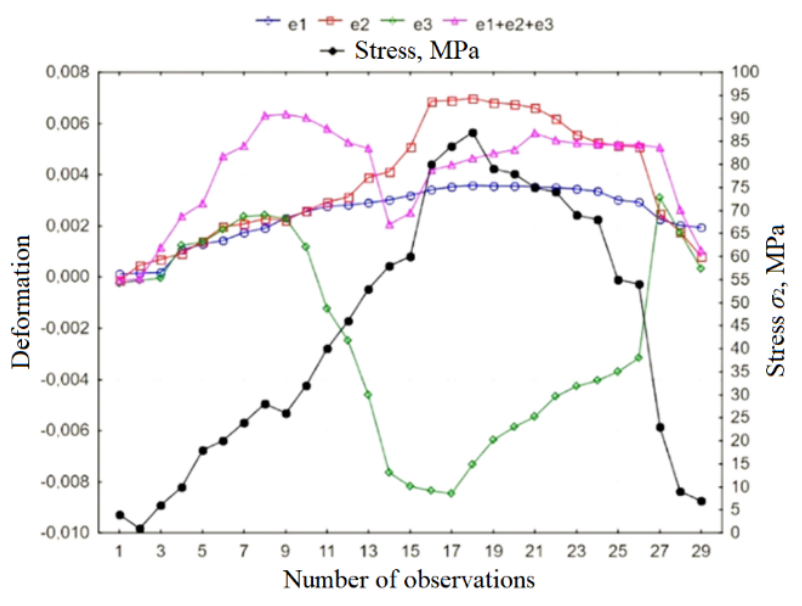

Figure 4. Deformation dependencies of a core sample oriented towards M point

Obvious physical interpretation corresponds to the obtained regularities. The analyzed rock mass layers have integral anisotropy both in terms of geomechanical and strength characteristics. The abovementioned formulates mathematical logic of changes (i.e. decrease) in the strength of each lithological layer. Predominantly, it concerns perpendicular stratification (vertical direction) to compare with higher values of the strength characteristics in horizontal direction corresponding to the stratification.

Since vertical direction is in accord with a well log, the unloaded strength condition of the rock mass layers (for the studied depth) will be typical for $M$ point if well pressure drops (Fig. 4).

If circular stresses $\sigma_{\theta}$ act, a borehole will experience higher compression by rocks, composing it; hence, a process of their vertical layer by layer separation becomes more intensive. Nevertheless, since horizontal effect of circular stresses is not critical, deformation tensor, directed towards $N$ point, can identify neither the clearly expressed rock disintegration process no creep parameter even in the case of major pressure drawdowns [25]-[27], (Fig. 5).

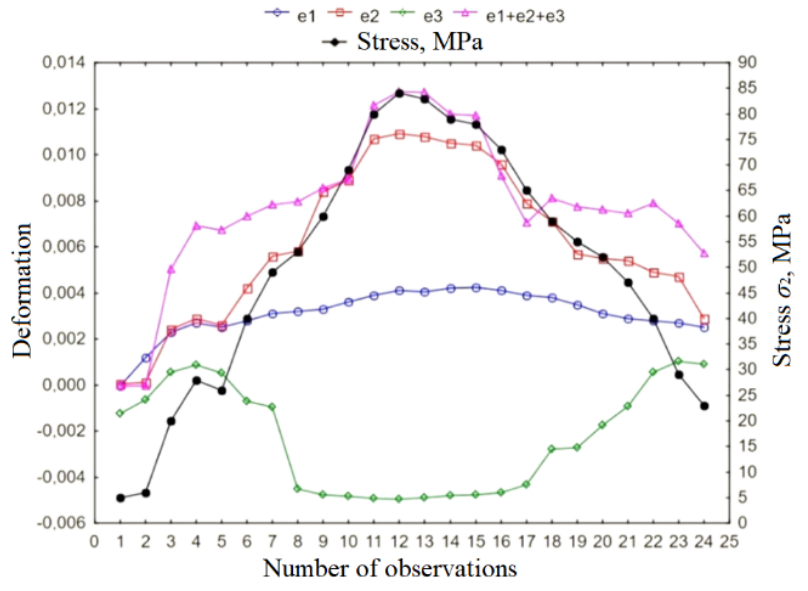

Figure 5. Deformation dependencies of a core sample oriented towards $N$ point

Figures 6 and 7 represent the results of neural network simulation of core sample strength (for hard and soft samples respectively.

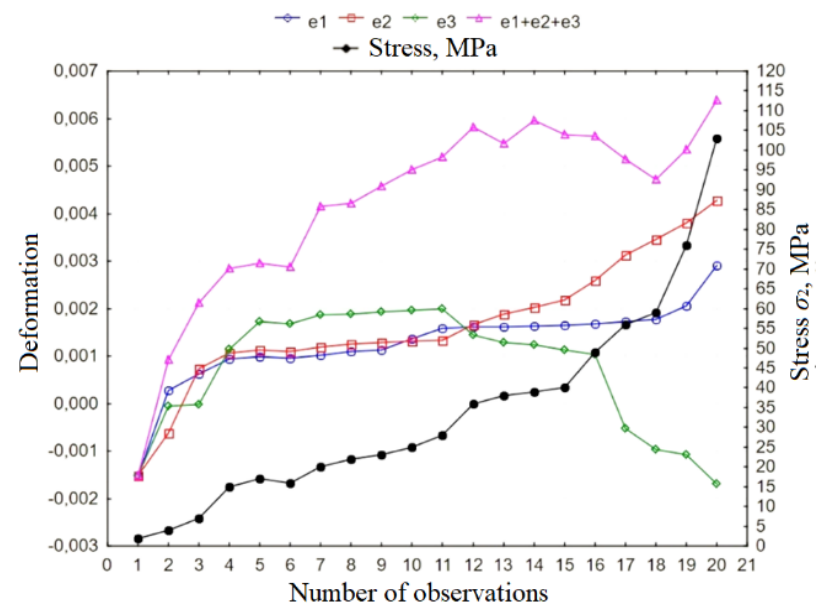

Figure 6. Deformation dependencies of hard core sample (clay)

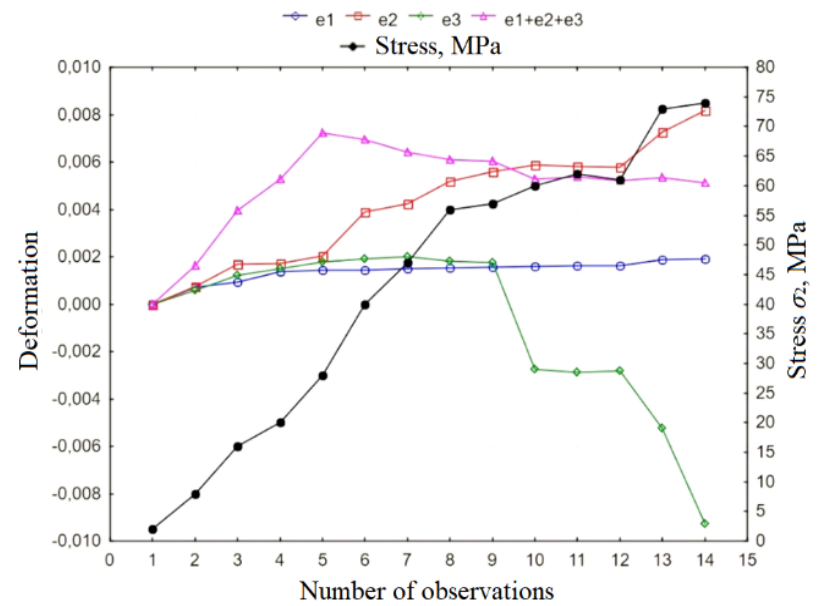

Figure 7. Deformation dependencies of soft core sample (sandstone)

Consequently, horizontal well drilling in terms of 5-30 atm (for geological objects of the Central Priobye) results in substantial disturbances of borehole structure stability within the interwell rock mass space [24].

To prove the idea, it is required to expand the basis of the mathematical model, represented earlier, involving changes in the strength of each lithological layer in accordance with the selected direction of the unloaded condition of the rock mass layers relative to the stratification planes. The abovementioned will make it possible to correlate stability of lithological layers of the rock mass and borehole geometry [28], [29].

The concept involves several aspects. The research represents one of them. It is identification of actual borehole length of horizontal/inclined well as for the stated rock mass depths to be mined. The data are required to specify specific values of rock pressure developed by the overlying formation since the former effects stability of deep well geometry.

A value of a vertical borehole share at $H_{0}$ level, being equal to $3200 \mathrm{~m}$ in terms of its zero incidence angle relative to the well axis; in terms of constant density of its rocks $\rho$, being equal to $2300 \mathrm{~kg} / \mathrm{m}^{3}$, and in terms of gravity acceleration $g$, being equal to $9.8 \mathrm{~m} / \mathrm{s}^{2}$, has been assumed as the initial depth (zero condition of the mathematical problem).

Following analytical and graphical dependencies (Figs. 812, Formulas 6-9) will demonstrate changes in a horizontal well borehole where inclination angle of a vertical share (before productive rock mass cutting-in) varies from 0 up to 45 degrees with $5^{\circ}$ increment. 


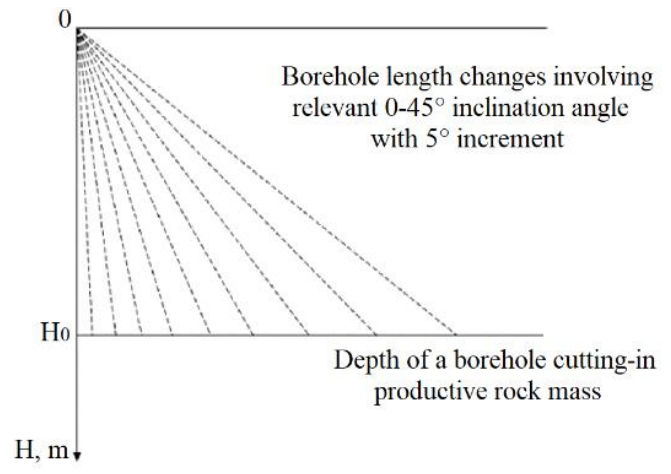

Figure 8. Schematic representation of borehole changes involving angle of inclination from a vertical axis

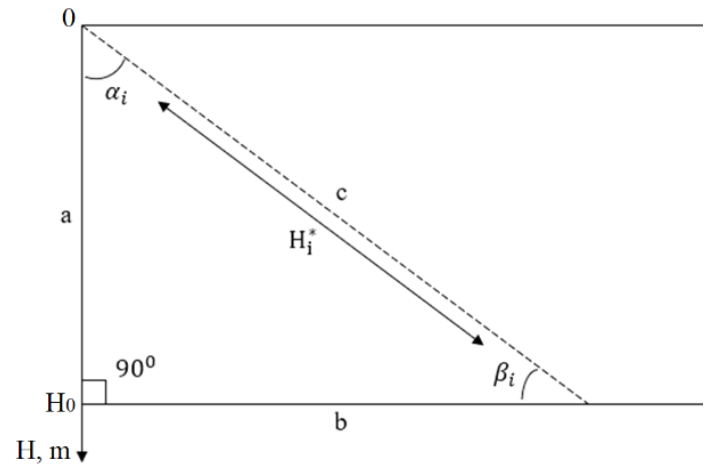

Figure 9. The detailed representation of the borehole length changes involving its angle of inclination from a vertical axis
According to the definition of sides of a right triangle (the sum of the angles is equal to 180 degrees), hypotenuse value (c) can be defined with the help of values of two corresponding catheti $(a, b)$ :

$c^{2}=a^{2}+b^{2}, c^{2}=\sqrt{a^{2}+b^{2}}$.

Since, cathetus value $(b)$ is unknown then hypotenuse value $(c)$, can be calculated taking into consideration adjacent angle $\beta_{i}$ to incidence angle of a wellbore $\alpha_{i}$ :

$c=\frac{H_{0}}{\sin \left(\beta_{i}\right)}$.

Where $H_{0}$ is length of a vertical wellbore before the cutting-in into the productive mass; $\beta_{i}$ is values of an adjacent angle relative to $\alpha_{i}$, Table 1 .

Rock pressure was calculated involving two methods: a traditional method (Formula 8) and according to Protodyakonov (Formula 9):

$$
\begin{aligned}
& P_{h o r}=\rho \cdot g \cdot H_{i}^{*} ; \\
& P_{h o r}=\rho \cdot g \cdot H_{i}^{*} \cdot \operatorname{tg}^{2}\left(\frac{90+\alpha_{i}}{2}\right) .
\end{aligned}
$$

Table 1 explains the content of (8-9) Formulas.

The rock pressure values (according to Protodyakonov) were obtained in such measurement units as $\mathrm{kgs} / \mathrm{m}^{2}$.

Table 1. The initial data to analyze rock pressure

\begin{tabular}{ccccccc}
\hline $\begin{array}{c}\text { Borehole } \\
\text { incidence angle } \\
\text { along the } \\
\text { proper axis } \alpha_{i}\end{array}$ & $\begin{array}{c}\text { Adjacent } \\
\text { angle } \beta_{i}\end{array}$ & $\sin \left(\beta_{i}\right)$ & $\operatorname{tg}^{2}\left(\frac{90+\alpha_{i}}{2}\right)$ & $\begin{array}{c}\text { Borehole length }\left(H_{i}^{*}\right) \\
\text { taking into } \\
\text { consideration adjacent } \\
\text { angle } \beta i, \frac{H_{0}}{\sin \left(\beta_{i}\right)}, \mathrm{m}\end{array}$ & $\begin{array}{c}\text { Rock pressure } \\
\text { (standard } \\
\text { calculation } \\
\text { procedure, } \\
\rho \cdot g \cdot H_{i}^{*}, \mathrm{MPa}\end{array}$ & $\begin{array}{c}\text { Rock pressure } \\
(\text { according to Protodyakonov), } \\
\rho \cdot H_{i}^{*} \cdot \operatorname{tg}{ }^{2}\left(\frac{90+\alpha_{i}}{2}\right), \mathrm{MPa}\end{array}$ \\
\hline 0 & 90 & 1 & 1 & 3200 & 72.128 & 72.176 \\
\hline 5 & 95 & 0.996 & 1.091 & 3212.528 & 72.410 & 73.452 \\
\hline 10 & 80 & 0.984 & 1.191 & 3249.390 & 73.241 & 74.723 \\
\hline 15 & 75 & 0.965 & 1.303 & 3312.972 & 76.674 & 76.809 \\
\hline 20 & 70 & 0.939 & 1.428 & 3405.704 & 79.585 & 79.638 \\
\hline 25 & 65 & 0.906 & 1.569 & 3530.839 & 83.288 & 83.342 \\
\hline 30 & 60 & 0.866 & 1.732 & 3695.150 & 88.068 & 88.112 \\
\hline 35 & 55 & 0.819 & 1.920 & 3907.203 & 94.161 & 94.220 \\
\hline 40 & 50 & 0.766 & 2.144 & 4177.545 & 102.019 & 102.073 \\
\hline 45 & 45 & 0.707 & 2.414 & 4526.166 & & \\
\hline
\end{tabular}

To reduce the measurement units to $\mathrm{MPa}$ (Table 1), it is required to divide the calculation results by a conversion factor 101971.6. Figures 10-12 represent borehole length changes, invol-ving various incidence angles and dependencies of rock pressure variations (the traditional calculation procedure, and that one according to Protodyakonov) respectively.

Consequently, a value of rock pressure, influencing the well wall stability at $3200 \mathrm{~m}$ depth (if vertical borehole is meant) being $72.1 \mathrm{MPa}$, cannot match its actual value at the same depth in terms of any incidence angle. Among other things, if incidence angle is $35^{\circ}$ than actual borehole length is $3907 \mathrm{~m}$ instead of $3200 \mathrm{~m}$ in terms of $88 \mathrm{MPa}$ rock pressure rather than in terms of $72.1 \mathrm{MPa}$. The difference is $15.8 \mathrm{MPa}$ or 158.91 atm which will intensify drastically the deformation of well walls due to the influence of rocks occurring along its borehole.

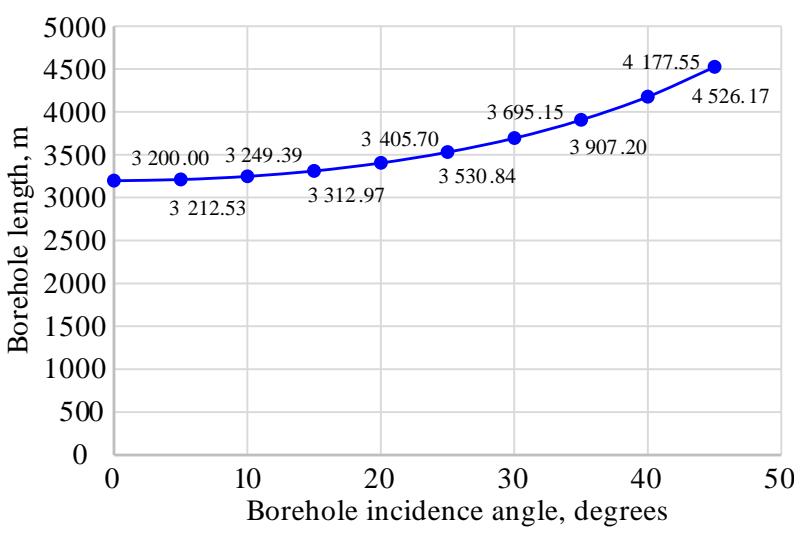

Figure 10. Borehole length changes, involving various incidence angles 


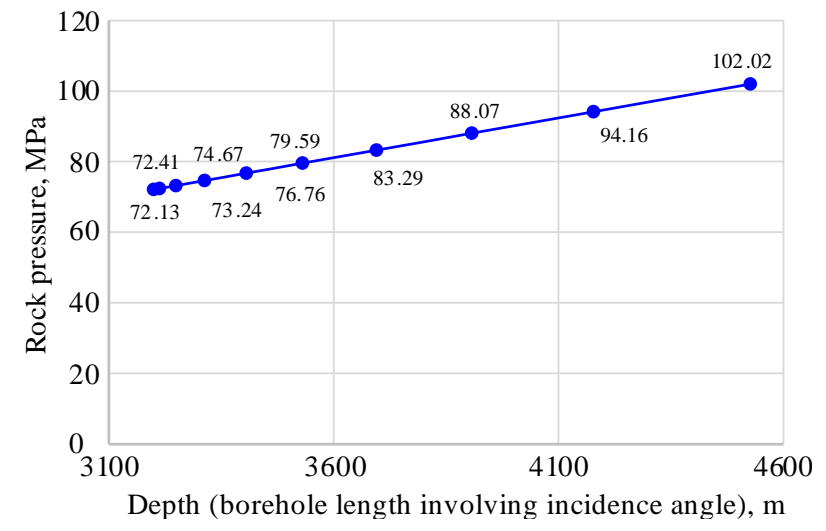

Figure 11. Rock pressure (a traditional calculation procedure)

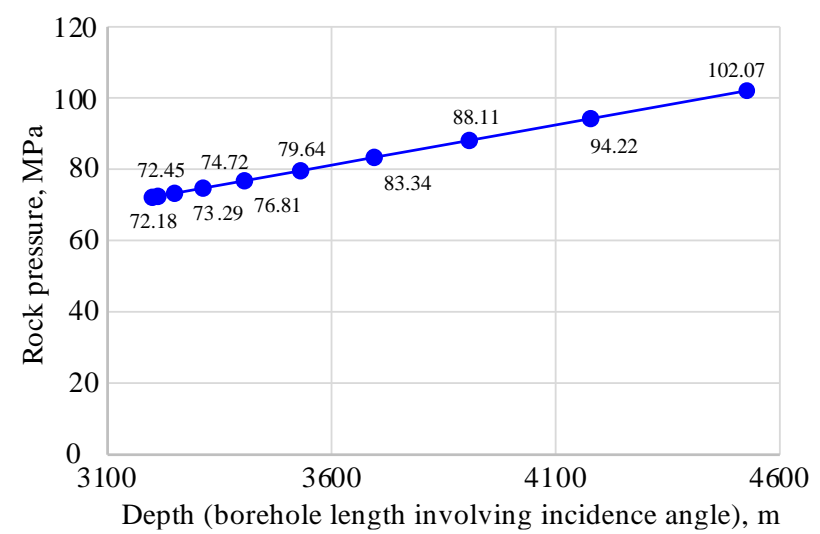

Figure 12. Rock pressure (a calculation procedure according to Protodyakonov)

\section{Conclusions}

The regularities of changes in deformation and spatial well stability within the complex reservoirs depending upon various process duties have been determined. A neural simulationbased model has been proposed to analyze deformation of rock mass layers having different strength characteristics.

Based upon the simulation, the deformation stability of well walls and samples of the studied rock mass with different strength characteristics have been forecasted. The following has been obtained:

- deformation values of both competent and soft samples from rock formation $\mathrm{UV}_{1}{ }^{1}$ of Las-Egan oil field will vary within -0.0015-0.0065 interval and within 0.000-0.0083 interval in terms of corresponding 2-102 and 2-75 MPa stresses respectively;

- deformation values of well walls will vary within 0.000-0.008 interval in terms of corresponding maximum stresses, being 72-83 MPa, if borehole length of a horizontal well is 3200 before productive formation cutting-in with $0^{\circ}$ incidence of the share;

- well wall deformation values will vary from 0.000 up to 0.013 in terms of corresponding stresses, being 72.1-88 MPa for a horizontal well length borehole before productive formation cutting-in (taking into consideration $35^{\circ}$ incidence angle of the share) which forms actual $3907 \mathrm{~m}$ borehole length rather than $3200 \mathrm{~m}$.

The findings have become a part of the recommendations concerning optimization of procedures to reextract hydrocarbon reserves within the framework of the project of the Ministry of Education and Science of the Russian Federation
"Methods to recover low-pressure gas of Cenomanian producing complex".

\section{Acknowledgements}

The research has been prepared within the framework of "Methods to recover low-pressure gas of Cenomanian producing complex” Project (\#0825-2020-0013, 2020-2022 years).

\section{References}

[1] Katanov, Yu.E., Vaganov, Yu.V., \& Listak, M.V. (2020). Geological and mathematical description of the rocks strain during behavior of the producing solid mass in compression (Tension). Journal of Mines, Metals \& Fuels, 68(9), 285-293.

[2] Deyk, L.P. (2009). Osnovy razrabotki neftyanykh i gazovykh mestorozhdeniy. Moskva, Rossiya: Tekhnopress, 570 s.

[3] Dobrynin, V.M., Vendel'shteyn, B.Yu., Kozhevnikov, D.A. (2004). Petrofizika (fizika gornykh porod). Moskva, Rossiya: Neft' i gaz, 369 s.

[4] Ermolaev, V.A., Larichev, L.N., \& Moseykin, V.V. (2008). Geologiya. Chast' 1. Osnovy geologii. Moskva, Rossiya: Izdatelstvo Moskovskogo Gosudarstvennogo Gornogo Universiteta, $622 \mathrm{~s}$.

[5] Zheltov, Yu.P. (1966). Deformatsiya gornykh porod. Moskva, Rossiya: Nedra, 198 s.

[6] Katanov, Yu.E., \& Yagafarov, A.K. (2016). Otsenka veroyatnosti deformatsii porod-kollektorov v nechetkikh usloviyakh. Estestvennye $i$ Tekhnicheskie Nauki, 4(94), 41-49.

[7] Katanov, Yu.E. (2014). Matematicheskaya model' protsessa nakopleniya i prostranstvenno-vremennoy evolyutsii ansamblya elementarnykh povrezhdeniy neft', gaz i biznes kak edinogo dinamicheskogo protsessa. Neft', Gaz i Biznes, (9), 60-63.

[8] Yagafarov, A.K., Kleshchenko, I.I., Popov, I.P., Vaganov, Yu.V., Katanov, Yu.E., Popova, Zh.S., \& Savina, M.E. (2017). Tekhnologii povysheniya produktivnosti skvazhin $i$ vozdeystviya na zalezhi uglevodorodov na mestorozhdeniyakh Zapadnoy Sibiri. Tyumen', Rossiya: Tyumenskiy Industrial'nyy Universitet.

[9] Yagafarov, A.K., Kleshchenko, I.I., Korotenko, V.A., Popov, I.P., Popova, Zh.S., Vaganov, Yu.V., Kuznetsov, N.P., \& Ruchkin, A.A. (2017). Geologo-promyslovye i tekhnologicheskie aspekty razrabotki neftyanykh mestorozhdeniy Zapadnoy Sibiri. Tyumen', Rossiya: Tyumenskiy Industrial'nyy Universitet.

[10] Popov, I.P., \& Zakharov, N.O. (2018). Obosnovanie flyuidodinamicheskoy modeli yuzhnogo neftyanogo mestorozhdeniya. Nauka $\mathrm{i}$ Mir, 1(5(57)), 59-66.

[11] Aleksandrov, V.M., Morozov, A.V., Popov, I.P., Lebedeva, R.G., \& Bulgakova, I.A. (2018). Detailization of the facial conditions for sedimentation of the (formula presented) productive layer with the purpose of specificating features of the geological structure. Journal of Environmental Management and Tourism, 9(5(29)), 932-946. https://doi.org/10.14505/Jemt.V9.5(29).05

[12] Degtiarev, D., Nesterov, I., \& Lintser, S. (2019). Theoretical basis of the dilatance regime in the development of hydrocarbon deposits in the Bazhenov formation. Tyumen 2019, 1-6. https://doi.org/10.3997/22144609.201900627

[13] Nesterov, I.I., Smirnov, P.V., Konstantinov, A.O., \& Gursky, H.-J. (2020). Types, features, and resource potential of Palaeocene-Eocene siliceous rock deposits of the West Siberian Province: A review. International Geology Review, 63(4), 504-525. https://doi.org/10.1080/00206814.2020.1719370

[14] Protod'yakonov, M.M. (1930). Davlenie gornykh porod i rudnichnoe kreplenie. Moskva, Rossiya: Glavnoe Gorno-Toplivnoe Upravlenie.

[15] Satter, A., Baldwin, J., \& Jespersen, R. (2000). Computer-assister reservoir management. Oclahoma, United States, $278 \mathrm{p}$.

[16] Yan, Ye., Yan, J., Zou, S., Wang, S., \& Lu, R. (2008). A new laboratory method for evaluating formation damage in fractured carbonate res$\begin{array}{llll}\text { ervoirs. } & \text { Petroleum } & \text { Science, } & 5(2),\end{array}$ https://doi.org/10.1007/s12182-008-0007-3

[17] Mackey, G.N. (2012). Provenance of Paleocene-Eocene Wilcox group western Gulf of Mexico basin: Evidence for integrated drainage of the southern Laramide rocky mountains and cordilleran arc. Geological Society of America Bulletin, (124), 1007-1024. https://doi.org/10.1130/B30458.1

[18] Makowitz, A., \& Milliken, K.L. (2002). Quantitative measurements of brittle deformation with burial compaction, Frio formation, Gulf of Mexico basin. Gulf Coast Association of Geological Societies Transactions, (52), 695-706. 
[19] Mcbride, E.F., Abdel-Wahab, A.A., \& Milliken, K.L. (2002). Petrography and diagenesis of half-billion-year-old cratonic sandstone (hickory). Llano Region, Texas, United Stateds: Bureau of Economic Geology, University of Texas at Austin, Report of Investigations, $74 \mathrm{p}$. https://doi.org/10.23867/RI0264D

[20] Shmyglya, N.S. (2019). Strukturnaya interpretatsiya litologicheskikh razlichiy uslovnoy zalezhi uglevodorodov. Vzaimodeystvie Nauki i $\mathrm{Ob}$ shchestva: Problemy i Perspektivy, (2), 64-68.

[21] Shmyglya, N.S. (2020). Poisk optimal'nykh geologotekhnologicheskikh parametrov massiva pri burenii. Problemy $i$ Perspektivy Razrabotki $i$ Vnedreniya Peredovykh Tekhnologiy, 55-57.

[22] Katanov, Yu.E. (2014). Mekhanizmy i printsipy modelirovaniya deformatsionno-prostranstvennoy neustoychivosti gornykh porod. Stroitel'stvo Neftyanykh i Gazovykh Skvazhin na Sushe i na More, (11), 19-23.

[23] Katanov, Yu.E. (2014). Matematicheskaya model' protsessa nakopleniya i prostranstvenno-vremennoy evolyutsii ansamblya elementarnykh povrezhdeniy kak edinogo dinamicheskogo protsessa. Neft', Gaz i Biznes, (9), 60-63.
[24] Katanov, Yu.E., Aleksandrov, V.M., \& Yagafarov, A.K. (2020). Geological and mathematical analogy of reservoir and polymer structures. TEST Engineering \& Management, 6977-6991.

[25] Koronovskiy, N.V. (2011). Geologiya Rossii i sopredel'nykh territoriy. Moskva, Rossiya: Akademiya, $230 \mathrm{~s}$.

[26] Koronovskiy, N.V., \& Yasamanov, N.A. (2011). Geologiya. Moskva, Rossiya: Akademiya, $194 \mathrm{~s}$.

[27] Kuznetsov, V.G. (2007). Litologiya. Osadochnye porody $i$ ikh Izuchenie. Moskva, Rossiya: Nedra-Biznestsentr, $513 \mathrm{~s}$

[28] Drits, V.A., Mccarty, D., Sakharov, B.A., \& Milliken, K.L. (2005). Insight into structural and compositional homogeneity-heterogeneity of some ancient calcian dolomites. Canadian Mineralogist, (43), 12551290. https://doi.org/10.2113/gscanmin.43.4.1255

[29] Day-Stirrat, R.J., Milliken, K.L., Dutton, S.P., Loucks, R.G., Hillier, S., Aplin, A.C., \& Schleicher, A.M. (2010). Open-system chemical behavior in deep Wilcox group mudstones. Marine and Petroleum Geology, (27), 1804-1818. https://doi.org/10.2113/gscanmin.43.4.1255

\section{Дослідження стійкості стінок свердловин при розкритті продуктивного масиву на базі нейромережевого моделювання}

\section{Ю. Катанов, Ю. Ваганов, М. Чейметов}

Мета. Розробка математичних моделей для оцінки деформації параметрів геолого-технологічної системи “масив - свердловина" в анізотропних середовищах.

Методика. Для досліджень використані математичне та нейромережеве моделювання напруженого стану системи “масив свердловина" в умовах геологічної невизначеності. Для дослідження ймовірності ускладнюють факторів при бурінні 3 точки зору математичного моделювання, необхідно зробити ряд припущень для деформаційно-міцнісних властивостей геологічних шарів масиву, що відповідають конкретним умовам буріння свердловин.

Результати. Розроблено математичну модель деформації ствола горизонтальної свердловини і геологічних шарів, розташованих уздовж даної конструкції, в умовах постійно діючих всебічних напружень. Реалізовано, в аналітико-графічному вигляді, один з базових аспектів принципу агрегування змін меж міцності кожного окремого літошару для ідентифікації істинного значення довжини ствола горизонтальної/похилій свердловини щодо заявлених розробкою глибин масиву. Встановлено закономірності зміни деформаційно-просторової стійкості свердловин у складнопобудованих колекторах при різних технологічних навантаженнях. Запропоновано нейромережеву модель дослідження деформації шарів масиву з різними характеристиками міцності (межами міцності).

Наукова новизна. Дана якісна та кількісна оцінка взаємовпливу геомеханічних характеристик масиву на деформаційнопросторову стійкість конструкції свердловин.

Практична значимість. Представлена можливість прогнозування деформації стінок свердловин з урахуванням різних характеристик міцності та структурно-геологічних характеристик масиву на базі нейромережевого моделювання. Представлений підхід включений до реєстру наукових напрацювань згідно з проектом “Технології видобутку низьконапірного газу сеноманського продуктивного комплексу”.

Ключові слова: напруження, нейромережа, деформаиія, гірський тиск, трансверсально-ізотропне середовище, прогнозування, ствол, свердловина

\section{Исследование устойчивости стенок скважин при вскрытии продуктивного массива на базе нейросетевого моделирования}

\section{Ю. Катанов, Ю. Ваганов, М. Чейметов}

Цель. Разработка математических моделей для оценки деформации параметров геолого-технологической системы “массив скважина" в анизотропных средах.

Методика. Для исследований использованы математическое и нейросетевое моделирование напряженного состояния системы “массив - скважина” в условиях геологической неопределенности. Для исследования вероятности осложняющих факторов при бурении с точки зрения математического моделирования, необходимо сделать ряд допущений для деформационно-прочностных свойств геологических слоев массива, соответствующих конкретным условиям бурения скважин.

Результаты. Разработана математическая модель деформации ствола горизонтальной скважины и геологических слоев, расположенных вдоль данной конструкции, в условиях постоянно действующих всесторонних напряжений. Реализован, в аналитикографическом виде, один из базовых аспектов принципа агрегирования изменений пределов прочности каждого отдельного литослоя для идентификации истинного значения длины ствола горизонтальной/наклонной скважины относительно заявленных разработкой глубин массива. Установлены закономерности изменения деформационно-пространственной устойчивости скважин в сложнопостроенных коллекторах при различных технологических нагрузках. Предложена нейросетевая модель исследования деформации слоев массива с различными прочностными характеристиками (пределами прочности).

Научная новизна. Дана качественная и количественная оценка взаимовлияния геомеханических характеристик массива на деформационно-пространственную устойчивость конструкции скважин.

Практическая значимость. Представлена возможность прогнозирования деформации стенок скважин с учетом различных прочностных и структурно-геологических характеристик массива на базе нейросетевого моделирования. Представленный подход включен в реестр научных наработок согласно проекту “Технологии добычи низконапорного газа сеноманского продуктивного комплекса".

Ключевые слова: напряжение, нейросеть, деформачия, горное давление, трансверсально-изотропная среда, прогнозирование, ствол, скважина 